\title{
La Famille Dansant. Investigating the Family Structure and Repertory of the Johannesénske Balletselskab
}

The performance history of the Johannesénske Balletselskab spans a long period. In different shapes, sizes and names the ensemble was on the road for 30 years. This article analyses the activities of the Johannesénske enterprise through the lenses of itinerant performance traditions. Two features are discussed in this article: the reliance on family members as performers and the ensemble's diverse repertory. The ensemble featured a repertory popular in its own time, consisting

chiefly of national and character dances as well as pantomimes. Arguably, an investigation of the ensemble's performance history offers information on little explored perspectives of nineteenth century Nordic ballet. In particular, the Johannesénske Balletselskab offers insights into family structures and the repertoire typical of itinerant ensembles. This information is also useful on a more general level, given that there were several ensembles similar to the Johannesénske travelling in the Nordic countries that functioned similarly to La famille dansant.

Through analysing the use of the repertoire, it can be shown that the Johannesénske enterprise was, in their programming, up to date as a "ballet ensemble".

The family kept up itinerant traditions through their use of children as performers and reliance on pantomimes. The Johannesénske ensemble is, therefore, especially valuable for revealing insights into dance practices and dance styles, which have, so far, been little researched.

Keywords: itinerant ballet ensemble, national dance, character dance, child performers.

BIOGRAPHY

Anne Margrete Fiskvik (PhD, Dr. of Arts) holds the position of Associate Professor at the Department for Musicology, Program for Dance Studies, Norwegian University of Science and Technology, Trondheim. She is also Chair of the same

program. She is the main editor (together with Marit Stranden) of the 2014 anthology (Re)Searching the Field. Festschrift in Honour of Egil Bakka. Recent articles include an account on itinerant dancing masters travelling Norway during the latter part of the eighteenth century: "Information uti Dands i Christiania

1769-1773" in Lidenskap eller levebrød. Utøvende kunst i endring rundt 1800 (2015) and "Working in Nordic Dance Venues" in Nordic Dance Spaces. Practicing and Imagining a Region (2014). anne.fiskvik@ntnu.no 


\section{La Famille Dansant. Investigating the Family Structure and Repertory of the Johannesénske Balletselskab}

\section{ANNE MARGRETE FISKVIK}

\section{THE JOHANNESÉNSKE BALLETSELSKAB - A LONG LASTING NORDIC ENTERPRISE}

The performance history of the Johannesénske Balletselskab spans a long period. In different shapes, sizes and names the ensemble was on the road for 30 years. This article analyses the activities of the Johannesénske enterprise through the lens of itinerant performance traditions. Two features are discussed: the reliance on family members as performers and the ensemble's diverse repertory. The ensemble featured a repertory popular in its own time, consisting chiefly of national and character dances as well as pantomimes.

The first version of the Johannesénske Balletselskab was founded by Norwegian-born Johan Fredrik Johannesén in $1851 .{ }^{1}$ His ten step- and biological children became active as performers from an early age. The ensemble operated mainly outside of the institutionalized theatres in the Nordic countries and offered a repertoire suitable to a variety of tastes and spectators.

\section{PREVIOUS RESEARCH AND SOURCE MATERIAL} Today, the Johannesénske Balletselskab has more or less fallen into oblivion. This small, itinerant family ensemble, specializing in national and character dances as well as pantomimes, has not triggered large scholarly interest. In fact, neither itinerant dance practices, nor the use of national and character dances on stage have been fashionable as research topics. Thus, investigating the Johannesénske ensemble can offer insights into an area of Nordic dance history outside of the typical 'dance canon'.
One reason why the Johannesénske Balletselsk$a b$ has fallen into oblivion could be attested to the simple fact that the enterprise started and ended in Norway. It was run by a Norwegian whose background and education is little known. Overall, this time period of Norwegian dance history has not been researched. In fact, the ensemble's extensive tour of Norway 1878-79 has only recently been rediscovered and documented by the author. ${ }^{2}$

Several itinerant dancers deserve to be better documented, for instance dancers like Martin Nürenbach and Michael and Doreothea Christiana Stuart. They travelled the Nordic countries a hundred years earlier than the Johannesénske, but share some common features, for instance in an accessible repertoire which could please a variety of different audiences. Their activities can be traced through advertisements and announcements in Nordic newspapers. ${ }^{3}$ Similarly, the present article on the Johannesén family is largely based on newspaper material published in Nordic papers between 1848-80. To the best of my knowledge, this material has neither previously been analysed in a dance context, nor has it been used to investigate the history of the Johannesénske in a more substantial way. Nordic dance scholars have so far not taken an interest in the ensemble, even if their research offer general insights into Danish, Swedish and Finnish dance cultures in the latter part of the nineteenth century. However, Swedish dance researcher, Lena Hammergren, has collected some material on Johannesén's work at the Tivolibolaget in Stockholm and wrote about her work there in $1895 .{ }^{4}$

Even if Nordic dance scholars, so far, have taken 
little interest in the Johannesénske enterprise, their travels and performances in Finland and Sweden have been of interest to a few Nordic theatre scholars. Finnish librarian, historian and theatre researcher Sven Hirn's extensive work on travelling artists have helped in piecing together a first picture of the family. ${ }^{5}$ For the itinerant perspective, more recent investigations have been done by theatre scholars, Claes Uno Rosenqvist and Thoralf Berg. ${ }^{6}$ Rosenquist's and Berg's research have been informed by material and sources similar to my own, which consists of material from newspapers: notices, advertisements and reviews as well as posters, copy-protocols of applications, theatre records and entries into church books. The Johannesénske performances were covered quite thoroughly in all the cities they visited, which have left us with a large amount of notices and reviews. ${ }^{7}$ Of course working with newspapers requires an attention to their aims and purposes as well as political and cultural agendas. ${ }^{8}$

\section{WHY RESEARCH A HALF-FORGOTTEN BALLET ENSEMBLE}

As pointed out by dance scholar, Sherill Dodds, the awarding of special values to western artworks has produced a canon within dance scholarship based on specific aesthetic qualities.' Companies and dancers contained inside the 'canon' are typically most well-known and recognized for being special in some capacity or another. If the Johannesénske Balletselskab has not been regarded worthy of this kind of attention, this is a fate they share with numerous other enterprises and dancers, especially itinerant ones. Moreover, the repertoire included in the dance canon is also rather limited..$^{10}$ For instance, the Johannesénske performed in a period where dance styles influenced by national romantic trends were developed and practiced within the classical ballet. Thus the Johannesénske family followed the desire of popular taste. However, even if national and character dances were manifested in the repertoire of ballet companies all over Europe during the latter part of the nineteenth century, dance scholars have tended to neglect their importance both as independent pieces and their integration in classical ballet. As pointed out by dance scholars, Lisa Arkin and Marian Smith, these dance types were used a lot during the nineteenth century, and were popular with audiences. They have nevertheless, to a large extent, escaped the attention of international dance scholarship. ${ }^{11}$ Existing research has tended to focus on well-known choreographers such as August Bournonville, whose extensive use of national and character dances have been investigated by dance scholars like Erik Aschengren and Knud Arne Jürgensen. ${ }^{12}$ Through investigating the repertoire of an itinerant enterprise like the Johannesénske family, some features emerge which can offer insights into the practices of more marginalized dance ensembles.

\section{SITUATING THE JOHANNESÉNSKE ENTERPRISE WITHIN NORDIC THEATRE DANCE}

In order to analyse the repertoire and family structure of the Johannesénske enterprise, a brief outline of how the ensemble can be situated within Nordic dance history must first be offered.

Firstly, it should be pointed out that the Johannesénske ensemble was active during a time that saw many changes in artistic tastes as well as developments and improvements in infrastructures. Most significantly, the building of railroads and more regularly running steamships made travelling easier in the Nordic countries. A variety of ships travelled along the Nordic coasts. In Norway, the Johannesénske family travelled along the coastline visiting cities that had never been offered ballet performances. Between 1878 and 1879 , they travelled all the way to Tromsø far up in northern Norway and continued down along the coast of Norway, ending up in the city of Kristiania. ${ }^{13}$

Better means of travelling aided itinerant life, but, as pointed out by Rosenqvist (2008), theatre activity in the second half of the nineteenth century cannot be analysed without taking into considerations political and cultural changes. ${ }^{14}$ During the thirty years of the Johannesénske enterprise, theatre laws had been changed, several theatre ensembles had been established and numerous theatres built in Nordic cities. In Norway, for instance, itinerant performing became easier after a new and more liberal theatre law was passed in $1877 .{ }^{15}$ This law made it less cumbersome to stage theatre activities outside 
of the privileged theatres and easier for the family to give performances. ${ }^{16}$

Given the Nordic perspective in this article it must be pointed out that the history of ballet and other types of dance developed differently in Denmark, Finland, Norway and Sweden. ${ }^{17}$ In both Sweden and Denmark the Royal Opera ballets were established during the seventeenth and eighteenth centuries. ${ }^{18}$ Audiences in Copenhagen and Stockholm could see classical ballet as well as other types of dance on a regular basis at the royal operas. Norwegian and Finish ballet history differ from that of Denmark and Sweden because their stately funded ballet companies were not founded until the twentieth century: in Finland 1922 and in Norway 1958. Norway was thus especially reliant on visiting dancers and ensembles. Ballet masters such as Johan Peter Strömberg and August Bournonville gave small tours in Norway between 1820 and 1850. Norway was not alone in receiving travelling artists; itinerant dancers and actors have, as previously pointed out, a long performance history in the Nordic countries, a tradition to which the Johannesénske enterprise belonged.

\section{ITINERANT PERFORMANCE TRADITIONS}

The Johannesén family was part of a several centuries long European and Nordic tradition of travelling artists which continued into the latter part of the nineteenth century. The many people who lived outside of the larger cities were reliant on visiting companies if they wanted to see ballet. There was therefore still a market for itinerant ensembles like the Johannesénske enterprise.

Surprisingly, the many stories of travelling dancers and ensembles visiting the Nordic countries have been little researched. During the latter part of the eighteenth century, performers such as Michael Stuart, Christina Doreothea Stuart and Martin Nürenbach often combined dancing and acrobatics. They performed both indoors and outdoors, offering a variety of entertainments. For instance, when the dancer and acrobat Michael Stuart gave performances in Danish and Norwegian cities in 1768-69, the program consisted of a variety of smaller dance numbers performed on tight or slack ropes. Sometimes Stuart's performances ended with a pantomime in the commedia dell'arte style. Other itinerant artists performed spoken theatre in addition to dance and pantomimes such as ropedancer, acrobat and entrepreneur Martin Nürenbach. He travelled Sweden, Norway and Finland between 1760 and $1780 .{ }^{19}$

Quite a few international companies visited the Nordic countries; some more exotic than others. Two African female dancers performed in cities along the southern coast of Norway in 1878. They were 'exhibited' for the benefit of those who were curious to see what female African dancers looked like. For a small fee, spectators could view them 'on display' as well as see them perform "National dances from Africa". ${ }^{20}$ The two African dancers were presented as exotic and half-primitive rarities; reported by the newspapers to eat grasshoppers and snakes. Suffice to say that even if this practice of showing off 'otherness' definitely comes across as racist today, it was quite typical for its time.

Less exotic, but more similar in structure to the Johannesénske were other ensembles such as the Swedish Goldkette Acrobat-pantomime og Balletselskab, which toured Sweden, Finland and Norway in the latter part of the nineteenth century. This was, like the Johannesénske, a family enterprise. The Goldkette, as well as other family ensembles, typically visited cities on the eastern and western coast of Norway. ${ }^{21}$ A common feature of most of them was that they offered a repertoire consisting of national and character dancing, often concluding with a pantomime. ${ }^{22}$ This was also the repertoire that ballet master Johannesén chose when developing his enterprise.

\section{BUILDING AN ITINERANT ENSEMBLE}

The Johannesénske enterprise was developed around the dancing children of two families with, altogether, ten siblings. Johan Fredrik Johannesén had become the stepfather of four gifted dancers/ performers when he married the widow Catharina Johanna Marvig (born Altenburg) in 1851.23 She was some ten years older than Johan Fredrik and had been married to Hans Marvig, another travelling artist whose enterprise had toured the Nordic 
countries between 1848-49. ${ }^{24}$ The Johannesénske ensemble grew as six more children were born into the Johannesénske family between 1851-59: Ida, Edmund, Jenny, Alfred, Augusta and Josefina. As the family was constantly performing in smaller and larger Nordic cities, the children were born 'on the road'. Ida was, for instance, born in Fredrikshald (Halden), Norway in 1851, Jenny in Copenhagen in 1853, Augusta in Sundsvall, Sweden in September 1857, whereas the youngest daughter, Josefina, was born in Vasa, Finland in 1859.25 The Marvig children were active in the early period of the ensemble, between 1850-60, whereas the six Johannesén children danced in the ensemble from 1860 to 1880 . In addition to the Marvig and Johannesén children, various guest artists were hired for a short- er or longer time during the first twenty years of the ensemble.

As previously mentioned, using children as performers was common within travelling families of the time. The four Marvig children that Johannesén became the stepfather of when he married were already quite experienced: the text of the poster beneath (Fig. 1) reveals that Hans and Catharina Marvig had featured Johanna and Carl as main attractions for performances taking place in Kristiania in 1848 .

Notice the illustrative drawing of the performer, which speaks of equilibrist balancing as well as juggling. The text of the advertisement announced a repertoire consisting of national dances, soli and a pas de deux, gymnastic numbers as well as balancing

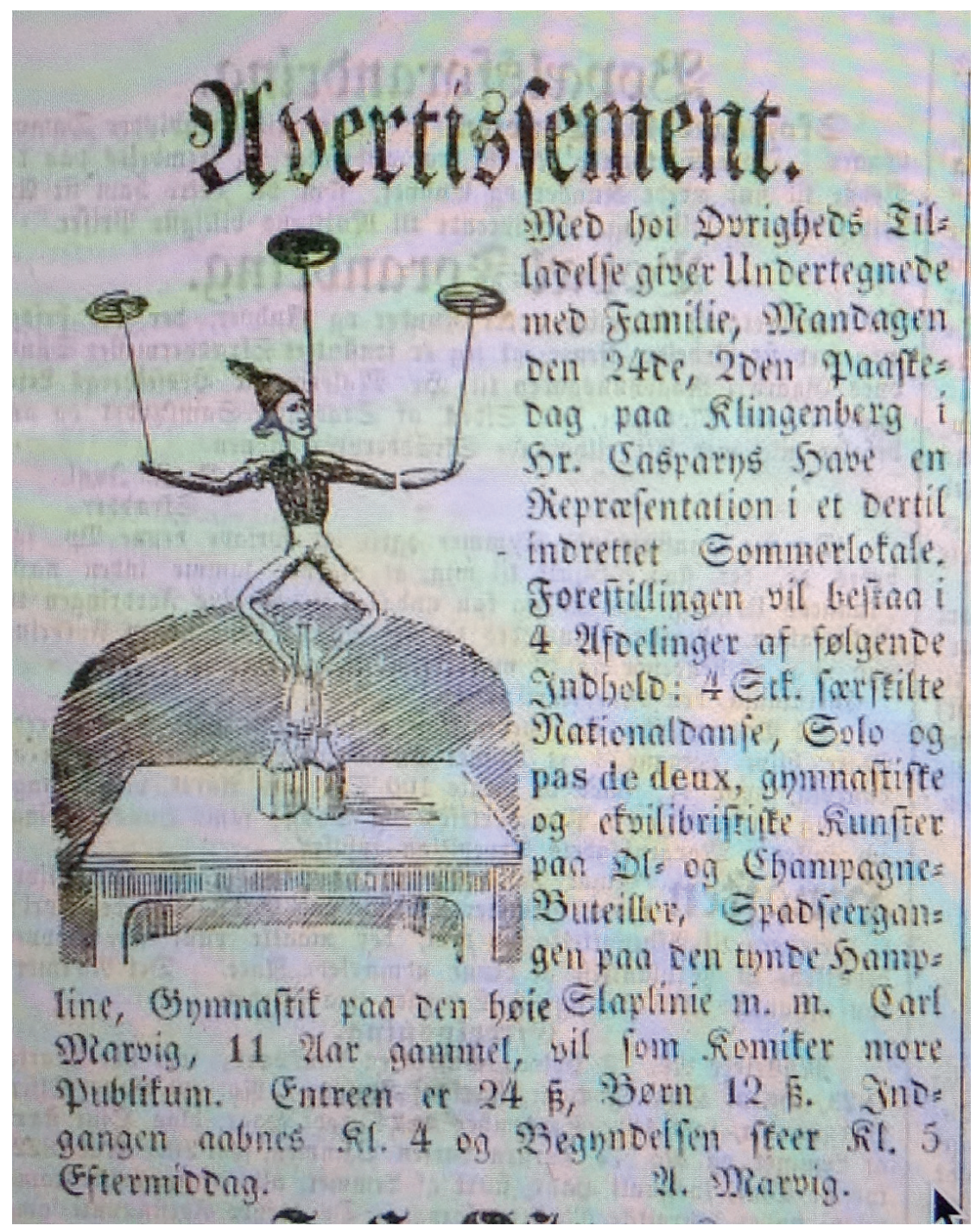

Fig. 1. Advertisement from Morgenbladet, 22 April 1848. 
acts on ropes and steel wires. This kind of repertoire had had long roots among itinerant dancers and was still popular in the latter part of the nineteenth century.

In the beginning of the Johannesénske ensemble, such a program consisting of acrobatics and juggling in addition to dance numbers was typical. As the years went by, the ensemble turned more into a 'pure' ballet and pantomime ensemble. $\mathrm{Na}$ tional and character dances remained a core feature throughout the ensemble's thirty years of existence.

\section{CHILDREN ON STAGE}

During the last ten years of the ensemble's performing life, the Johannesénske only featured family members. By 1878 they were all adults, but Norwegian newspapers liked to point out the family aspect of the ensemble. In Romsdals Budstikke, 6 June 1878 it was termed "La famille dansant". All the 'children' had, however been on stage since early childhood. Following itinerant tradition, the children were expected to contribute as soon as possible. Children were systematically trained into making early debuts as performers: "The children were rapidly placed before the public, usually in debuts as Cupids or attendants on Zephyr, miniature Harlequins or Pierrots, and 'skinwork' parts such as monkeys and other small 'animals'. A few years later they would be performing character folk ballets or interludes, particularly as peasants, harvesters and Italian comedy figures." 26

This description fits very well the Johannesénske ensemble; both in regard to the roles and repertoire performed. Various posters and advertisements list the Marvig and Johannesén children with contributions according to age and skill. The above-mentioned Carl Marvig was, for instance, regarded as especially talented and thus one of the star attractions of the Johannesénske ensemble between 1851 and 1858. He developed into a dancer of international standard and continued his career as premier danseur at the Royal opera ballet in Sweden as well as in St. Petersburg, before settling in New York. ${ }^{27}$ Finnish historian, Sven Hirn, even claimed that Carl Marvig was the family's main attraction and that when he left in 1858, this was a great loss to the Johannesén- ske ensemble. ${ }^{28}$ However, a number of sources has pointed out that the other children were also highly skilled. According to the journal Idun, the Johannesén children were trained in St. Petersburg under the Swedish ballet master Christian Johansson. ${ }^{29}$ This information has, however, not yet been verified. What is known is that the family performed and possibly lived in St. Petersburg between 1860$65 .{ }^{30}$

The Johannesén children were featured on various programs from ca 1856. A few theatre posters from performances staged by Johan Fredrik Johannesén in Åbo (Finland) in 1860 have been preserved. These give information on casting and repertoire. As can be seen below (Fig. 2), three of the Johannesén children performed in a repertoire that emphasized character and national dances as well as pantomimes.

The poster shows the involvement of the children as well as the typical repertoire featured. Ida and Edmund, at the age of eight and nine, danced three numbers. They opened the performance with a comedy-ballet, Den tapre Lanciern och Marketenterksan (The Brave Lancier and the Market Girl) and continued with a Dalpolska as well as a Pantomine ballet Matrosens Hemkomst - Pantomime Ballet (The Homecoming of the Sailor, Pantomime Ballet). A major asset for this particular performance were some hired guest dancers, an "Arabian family"; a father and two daughters who danced Arabian inspired numbers and, according to Hirn, attracted a considerable audience. ${ }^{32}$ However, whether this oriental family and their dances were genuine remains unclear. It was, after all, quite typical for this time to use costumes and scenery to create the illusion of a given exotic place, whereas steps and movements remained typical to the standard steps of national and character dancing.

The above poster also reveals that the children were featured in the closing pantomime, Den Brasilianska Apan (The Brazilian monkey), with characters inspired by the commedia dell'arte. Jenny, at the age of seven was given the role of Colombine. Star dancer, Carl Marvig, acted and danced the role of Cassander, and Johan Fredrik Johannesén performed the role of Pierrot. All in all, the program speaks of a variety of numbers that would please 


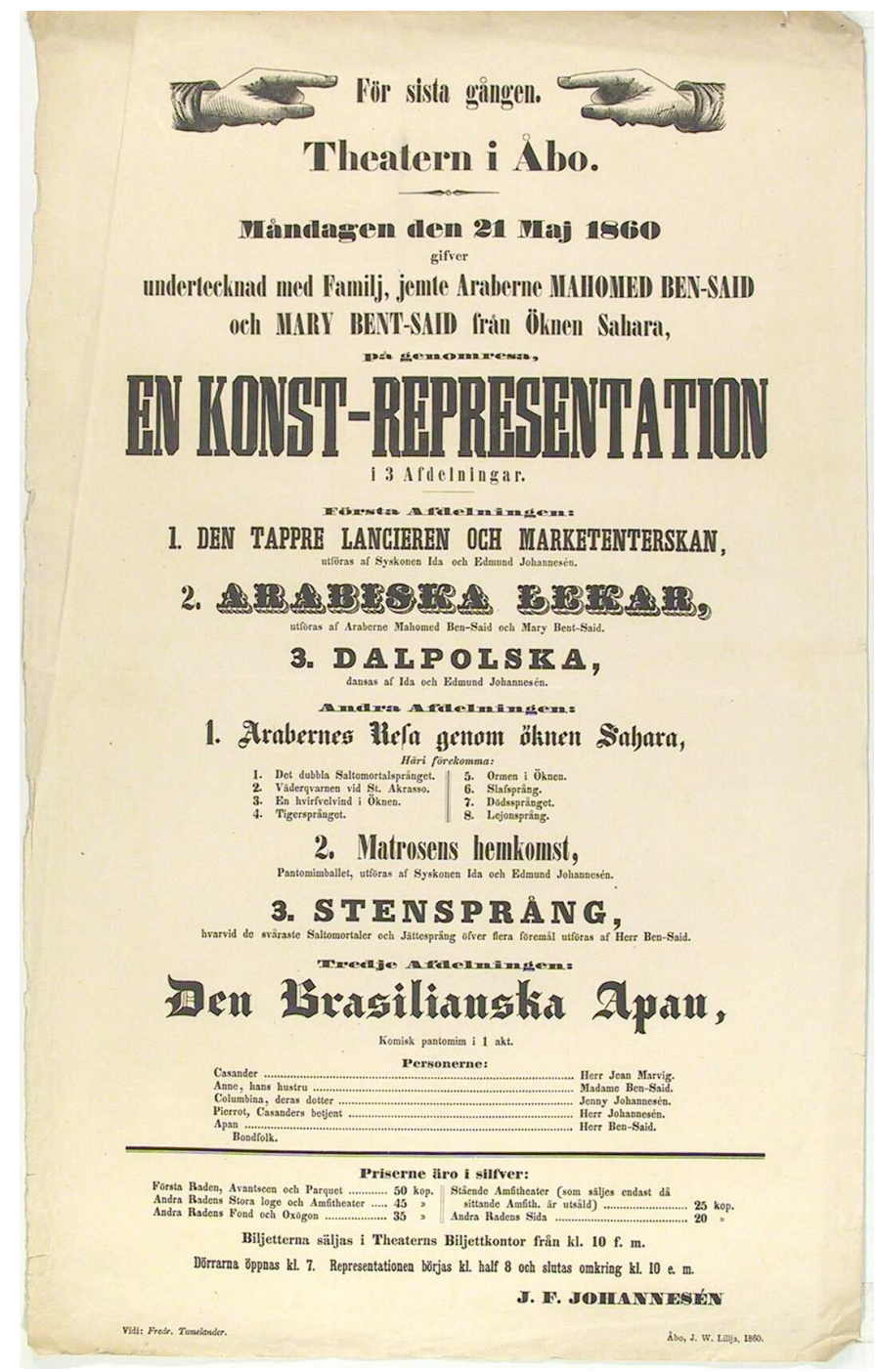

Fig. 2. Poster from Åbo (Finland), 20 May 1860.31

different kinds of audiences. Rosenqvist has pointed out that during their long journey in the Norrbotn Region 1876-77, the Johannesénske Balletselskab represented a form of theatre that was on its way to becoming extinct, but which was still appreciated by the audience. ${ }^{33}$ A review from Pitea (Sweden) shows that, at least in this city, people from different social classes attended the Johannesénske performances. Interestingly, the pantomimes were regarded as old fashioned and suitable for the education of the lower classes. ${ }^{34}$ The variety of numbers was expected and appreciated by audiences, even if the mixing of fashionable ballet-trends (national and character) with pantomimes was considered typical of an older itinerant tradition.

\section{NATIONAL AND CHARACTER DANCES}

If pantomimes were regarded as old fashioned, national and character dances were a highly fashionable part of the Johannesénske repertoire. It is not always so easy to distinguish between "national, folk and character dances". In the early part of the nineteenth century, the word 'character' was associated with the folk, i.e. dances which represented a given nation. As pointed out by dance scholar Susan $\mathrm{Au}$, "[c]haracter dancing borrows various elements from given dance forms in order to create the illusion that an authentic folk or social dance is being performed." ${ }^{35}$ More specifically, this can be seen in the body language and style of the dancing: "Among these elements are steps and leg gestures, head and arm movements, carriage of the body, partnering 
and linking, group formations, floor patterns, and dynamic qualities such as rhythm, flow, and sense of weight. Representative costumes may be worn, and the ballet's score may incorporate musical characteristics of the dance type." 36

Popular character dance adaptations for ballet typically include the national dances of Hungary, Russia, Poland, Italy, Spain, Scotland, the Tyrol, eastern and central Europe. According to dance historian Lynn Garafola, these dances represented a primitive 'other', while at the same time revealing the existence of an exotic-erotic hierarchy, topped by Spanish dances. ${ }^{37}$

Inspiration from folk dances had also been typical of eighteenth century dance styles and were still favourable in the next century. In fact, they blossomed in accordance with national romantic trends in the other arts. ${ }^{38}$ Thus, during the nineteenth century, a heavy reliance on national and character dances was seen in ballet companies all over Europa as well as in the Nordic countries. Around the 1830s and 1840 s, a veritable craze for folk-derived forms on the stage as well as the dance floor developed. At the Paris opera, for instance, which served as the 'centre' of romantic ballet during the first half of the nineteenth century, national dances figured in over three-quarters of the ballet performances. Not only European, but also Russian ballet was heavily influenced by folk dances. Dance historian Yuri Slonimsky has, for instance, emphasized the influence of various fairs and festivals on Russian ballet. ${ }^{39}$

Advertisements and notices for the Johannesénske Balletselskab reveal that the names 'national' and 'character dances' were used interchangeably. From the previously mentioned poster from Åbo, it can be seen that the siblings, Ida and Edmund, danced a Rustic Russian Dance (Rysk landtlig Nationaldans). Johan Fredrik performed an English Hornpipe. ${ }^{40}$ Nordic dances were also featured, for instance Dalpolska, which indicates a dance from the region Dalarne in Sweden. Quite a few of the dances were given names, which was meant to reflect the ensemble's 'Nordicness': "Like costumes, national dances were also markers of authenticity and suppliers of local colour [...] they could serve a narrative as well as decorative end." ${ }^{41}$ Bringing out Swedish, Finnish and Norwegian features could have been a way to honour the distinct features of the different Nordic countries.

A poster (Fig. 3) from performances given by the Johannesénske in St. Petersburg in 1862, depicts Augusta (six/seven years) and Alfred (seven/eight years). The illustration gives some indications of a certain carriage of the body, steps and leg gestures as well as representative costumes.

A 'national dance' of some sort is indicated by the costuming, the way they are holding each other as well as the lifted attitudes of the front foot. ${ }^{43}$ If ballet master Johannesén followed the customs of the time, the steps of the dance would have been taken from a series of standardized steps used to display folk character: "Ballet tended either to reflect the developing interest in other countries and other people by offering 'national dances' which were more evocative of style than accurate of step." 44 Thus the Johannesénske numbers could characterize a given country, or they could give characteristics of persons. For instance, a number frequently shown was Gammel og Ung - dobbel Karakterdands (Old and Young, double character dance). Danced by Edmund and Josefina, one can imagine that Edmund portrayed the older persons, and Josefina the younger, and that their body language, steps and costumes would emphasize these characteristic.

\section{CLASSICAL BALLET - OR NOT?}

The Johannesénske ensemble also featured numbers with names more typical of classical ballet, such as "one-act ballets" and "divertissements". To what extent these relied on steps and aesthetics derived from classical ballet remains unclear. From the source material, it is difficult to judge to what degree the actual steps of these differed from that of the national and character dances. The Spansk Balletdivertissement (Spanish Ballet Divertissement) advertisement in Åbo in 1862 could have relied more on elements of national and character dance than on classical ballet steps. Other names found in the Johannesénske family's repertoire are suggestive of a story of some sorts, for instance Josofinas Navnedag - Ballet $i$ en akt (Josofina's Name Day - ballet in one act). Alternatively, a comic content is implied in pieces like De levende Marionetter - Komisk Ballet $i$ 
en akt (The Living Marionettes - comic ballet in one $a c t$ ). It can be seen that the titles often involve some kind of characterization. As already stated, it is likely that the vocabulary of all the dance numbers were rather similar. Differences would be brought out in costuming and by adding specific steps typical of a given folk dance, for instance a mazurka step.

On the continent, there was a growing tendency to be preoccupied with issues related to human beings. As pointed out by Alexandra Carter: "Two revolutions, the French and the Industrial, had precipitated the change in subject matter of the [romantic] ballets from mythology and allegory to more direct representations of humankind and human dilemmas." 45 If the themes of the Johannesénske repertoire show interest in human drama, this is done with a humoristic touch. The titles of their repertoire reflect more on cosy events of everyday life than an interest in human dilemmas. Narrations as well as characterizations seem to have been typical.

\section{PANTOMIMES}

Throughout their thirty years of performing, the Johannesénske enterprise continued to feature pantomimes. This type of comic entertainment - mimed theatre interspersed with dance - portrayed easy-going narratives. The featuring of pantomimes is interesting because it reflects both Nordic as well as itinerant performance traditions dating back several hundred years. Traditionally, pantomimes could be staged with a small number of performers; they were

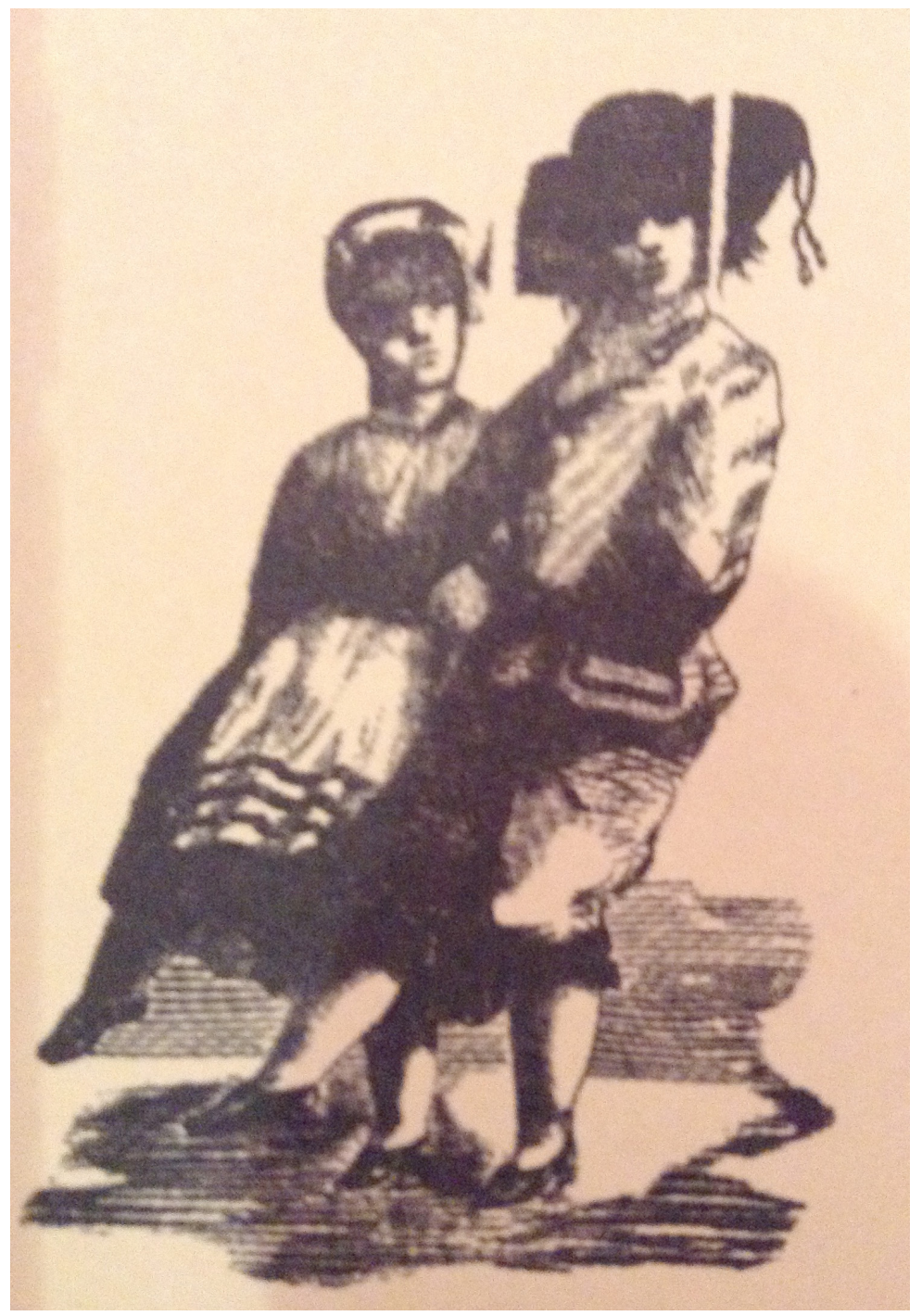

Fig. 3. An enlarged excerpt from a poster advertising performances in St. Petersburg in $1862 .{ }^{42}$ 
entertaining and suitable for audiences of all ages. ${ }^{46}$ The pantomimes were often saved to the end as a comic treat, a tradition that was continued by the Johannesénske Balletselskab and other ensembles. As already pointed out, the Johannesénske Balletselskab was not alone in showing pantomimes. Several other visiting ballet companies performed them during the latter part of the nineteenth century. For instance, when the Goldkette Acrobat-pantomime and Balletselskab toured Norway in 1880 their program also ended with a pantomime. ${ }^{47}$

The Johannesénske pantomimes often borrowed comic titles and themes derived from commedia dell'arte, this can be seen in the above advertisement from Åbo where Den Brasilianske Apan (The Brazilian Monkey) concluded the program. Another number frequently featured was Harlequin - mekanisk statu (Harlequin - Mechanical Statue). Interestingly, this latter piece is still performed in the Copenhagen Tivoli, a contemporary theatre which bases its repertory on pantomimes. ${ }^{48}$

Dancing was part of the Johannesénske pantomimes. In an advertisement in Tonsberg Blad, Harlequin - Mechanical Statue was categorized as a Komisk Pantomine med Dands i 2 tableauer (Comic Pantomime with dance in 2 tableaux). Reviews show that they were well received by audiences. ${ }^{49}$ In fact, such pantomimes had been highly appreciated in all the Nordic countries. In 1860, a Swedish/Finnish journalist in Åbo Underrättelser even considered them the best part of the program. ${ }^{50}$ However, as previously pointed out, in the 1870 s pantomimes had started to be regarded as a bit old fashioned, at least in Sweden. Rosenqvist has pointed out that a review in Norrbotten Posten (14 June 1877) described the Johannesénske pantomimes as out-dated and unfashionable for the better-educated audiences of the city of Pitea. The reviewer stated that the pantomimes served to entertain "the less educated and younger part of the audiences", thus implying that the divertissements and national and character dances were more geared towards more sophisticated audiences. ${ }^{51}$ Reviews from the Norwegian tour 1878-80 reveal no such hierarchical preferences between dance numbers and pantomimes. This could indicate different tastes and preferences in Norwegian and Swedish spectators, Norwegian au- diences being more unfamiliar with ballet. Several Norwegian cities had, after all, never been visited by a ballet ensemble prior to the Johannesénske Balletselskab's tour.

\section{"LA FAMILLE DANSANT" IN RETROSPECT}

This article started out with stating some purposes and aims for studying a half-forgotten ensemble like the Johannesénske Balletselskab. Arguably, an investigation of the ensemble's performance history offers information on little explored perspectives of nineteenth century Nordic ballet. The Johannesénske enterprise is an example where (as pointed out by Hammergren) "[n]ational or regional sources hitherto not investigated can offer possibilities for new interpretations or complementary analyses." 52 The The Johannesénske ensemble is, therefore, especially valuable for revealing insights into dance practices and dance styles, which have, so far, been little researched. In addition, the Johannesénske Balletselskab offers insights into family structures and the repertoire typical of itinerant ensembles. There were, after all, many ensembles similar to the Johannesénske travelling in the Nordic countries, which functioned similarly to "La famille dansant". Several ensembles developed around children, with the possibilities and limitations that this entailed. Advertisements in local papers speak of cheerful acts offering entertainment and laughter. It mixed fashionable and old-fashioned trends. This was a repertoire, which spoke to different types of spectators and typical of several travelling companies. However, information specific to the Johannesénske can be found in the source material, for instance revealing national romantic tendencies when integrating Swedish folk dances such as Dalpolska in the program. In addition, some differences between the Nordic countries regarding the reception of the repertoire have been detected. Norwegian audiences seem to have been more appreciative of the pantomimes than Swedish ones.

Most reviews examined by Nordic colleagues and myself show that the Johannesénske performances were praised for presenting good quality dancing. Even if it is impossible to know what the technical level was like, it is highly likely that it was 
not quite as high as that of the royal ballets of Copenhagen and Stockholm. However, the ensemble attracted a large Nordic audience that enabled the family to continue their itinerant performing for thirty years.

My intention in this article has not been to argue over qualitative evaluations of the Johannesénske Balletselskab. The quality would have differed according to who was dancing and reviews would be coloured by the taste and knowledge of the writers. Through analysing the use of the repertoire, it can be shown that the Johannesénske enterprise was, in their programming, up to date as a "ballet ensemble". The family kept up itinerant traditions through their use of children as performers and reliance on pantomimes. Arkin and Smith have claimed that national dances played an enormous important role in ballet and were considered a salient force within it during the nineteenth century. This craze for national and character dance has suffered neglect in western dance research: "That is, it has suffered something of the same fate as the 'juste milieu' paintings and the colporteur literature of the same age. These were extremely well known to the nineteenth century but until fairly recently were marginalized as unworthy of serious consideration." 33 Perhaps the achievements of the Johannesénske Balletselskab can be analysed in a similar manner. Even if the Johannesénske Balletselskab offered a repertoire highly popular in its own time, this later lost the interest of international scholarship. Arguably, the fact that the Johannesénske repertoire relied on national and character dances could have contributed to the meagre interest in the ensemble among Nordic theatre scholars.

\section{SOME CONCLUDING REMARKS}

Sven Hirn, who, to the best of my knowledge, was the first to document some of the ensemble's travels in Finland, has credited the Johannesénske enterprise for varied programming as well as their stubbornness and faithfulness towards the dancing business. ${ }^{54}$ Even so, a slightly condescending tone can be detected in his analysis. In fact, he has described the enterprise as "prosaic". Rather than seeing this as faulty, one could argue that this prosaic nature was the essence in which the ensemble was rooted: the everyday, practical and easily accessible nature of the enterprise gave the family it's "bread and butter". A varied repertoire suited different types of spectators. A versatility in programming was needed when travelling to remote Nordic cites never previously visited by ballet ensembles. Moreover, versatility continued to be important also after the family had settled in Christiania.

The Johannesén family continued to make an impact on Nordic theatre dance even after the ensemble was dissolved in 1880. Johan Fredrik Johannesén opened a dance school in Kristiania where several of his 'children' were employed. Augusta Johannesén became a leading female ballet dancer in Kristiania. The two sons, Alfred and Edmund, worked as dance teachers in Kristiania and Drammen. Ida and Josefina Johannesén both married and settled in Sweden where they worked as dancers, dance teachers and theatre directors in Stockholm and other Swedish cities. ${ }^{55}$

The Johannesénske Balletselskab brought ballet out 'to the people' and for this they deserve a place in Nordic dance history. It was not the only ballet ensemble that visited the Northern hemisphere, but it was a truly Nordic enterprise. The ensemble adapted their style and repertoire to suit many different types of audiences, and in this, they became neither really famous nor notorious.

There are still many gaps in the history of the enterprise. For instance, a more detailed overview of their performances before 1878 is needed. Perhaps the family visited some of the Baltic countries, or other European countries. How were they received? Did they perform a different repertoire? If, as has been indicated by a few sources, they did in fact spend several years in Russia, did they live in St. Petersburg and what kind of dance education did the children receive? More knowledge about the type of training Johan Fredrik Johannesén received is also needed in order to better understand his motivation for a performance life on the road. Moreover, even though I have not addressed the question of propriety in this article, this remains a key word in how the ensemble adapted to the social and cultural demands and norms of the time. More research into the above aspects can, hopefully, serve to contex- 
tualize the ensemble's repertoire and construction even better. It is to be hoped that the many gaps that still exist regarding their existence will be researched further. 


\section{NOTES AND REFERENCES}

1 Johan Fredrik Johannesén (1826-1900) was born in Kristiania, Norway. He was, first and foremost, an acrobat who, from 1848 and onwards, worked with different itinerant theatre ensembles that travelled Denmark, Sweden, Finland and Russia.

2 Anne Fiskvik, "Itinerant Challenges and Newspaper Support: The Johannesénske Balletselskab's Norwegian Tour 1878-1879" in På Spissen, no. 3, pp. 1-28, 2015, DOI: http://dx.doi.org/10.18862/ps.2015.301. This recently published article gives an account of the typcial challenges an itinerant ensemble could encounter while on the road. Great care has been taken to avoid overlap between this article and the current one, but some issues on being outside of the canon are discussed in both.

3 For more information on itinerant dancing in the Nordic countries, see Anne Fiskvik, "Information Udi Dands" in Lidenskap og Levebrød, Randi Selvik, Sven Gladsø, Ellen Gjervan, eds., Fagbokforlaget, Bergen 2015, pp. 287-314 and Anne Fiskvik, "Nemo in orbe est. The Norwegian Adventures of Michael Stuart" in Play, Places and Participants, Randi Selvik, Svein Gladsø, Anne Fiskvik, eds., Ashgate, Fordham 2016.

4 Lena Hammergren, Ballerinor och barfotdansöser. Svensk och internationell danskultur runt 1900. Chora - skriftserie for danseforskning, vol. 4, Carlssons Bokförlag, Stockholm 2002, p.12. For more general information on Nordic dance history, see also Nordic Dance Spaces. Practicing and Imagining a Region, Karen Vedel, Petri Hoppu, eds., Ashgate, Farnham 2014. Note that the time period 1850-1900 has been less researched than the period closer to the fin de siècle and the twentieth century.

5 Two of Sven Hirn's books are invaluable for a Nordic dance perspective on Johannesén as well as other itinerant artists. Sven Hirn, Våra danspedagoger och dansnöjen. Om undervisning och evenemang före 1914, Svenska litteratursällskapet i Finland, no. 505, Helsingfors 1982, pp. 86-8 and Sven Hirn, Den Gastronomiska Hästen. Gamla nordiska artistaffischer, Bokförlaget Atlantis, Helsingfors 2002.

6 See for instance, Claes Rosenquist's anthology Artister i norr: bottnisk och nordnorsk teater och underhållning på 1800-talet, Kungl. Skytteanska Samfundet, Umeå 2008. See also Claes Rosenqvist et al's anthology Teater i Mittnorden. 1800-tallets senare del. Material, metoder och analyser, Umeå Gigraf, Gideå 1998. For an analyses of the activity of several itinerant Nordic theatre troupes in the northern and middle parts of Norway, Finland and Sweden, see Att resa var nödvändigt: äldre svensk landsortsteater, Claes Rosenqvist, Dag Nordmark, eds., Vildros, Gideå 1990.

7 It is worth noting that many reviews and notices published in Nordic newspapers prior to 1920 were not signed, but published anonymously.

8 For an account of newspapers as source material, see for instance Fiskvik, "Itinerant Challenges and Newspaper Support”, op. cit., pp. 2-6.

9 The phenomenon of canons within dance is discussed in Sherrill Dodds, Dancing on the Canon. Embodiements of Value in Popular Dance, Palgrave Macmillan, Basingstoke 2011.

10 According to the dance researcher Beth Genné, the dance canon is a relatively modern construct, largely formed in the first decades of the twentieth century by figures such as Ninette de Valois through her establishment of the British Royal Ballet.

11 Lisa Arkin and Marian Smith, "National Dance in the Romantic Ballet" in Rethinking the Sylph. New Perspectives on the Romantic Ballet, Lynn Garafola, ed., Wesleyan University Press, London 1997, p. 11.

12 Bournonville relied extensively on all types of national and character dances in his work. See for instance Erik Aschengren, "Bournonville, August" in International Dictionary of Ballet, vol. 1, St. James Press, London 1993, pp. 188-92. See also Knud Arne Jürgensen, The Bournonville Tradition, The First Fifty Years 1829-1879, vol. I: A Documentary Study, Dance Books, London 1997.

13 Fiskvik, "Itinerant Challenges and Newspaper Support", op. cit., pp. 7-8.

14 Rosenvist, op. cit., 2008, pp. 19-22.

15 According to dance researcher, Torkel Bråten, the law was passed 1 February 1877 and confirmed with a Royal Resolution on 12 May 1877. (Torkel Bråten, Retten til a framfore offentlige forestillinger i Norge 1814-1875, MA thesis, Oslo University, Oslo 2015. More details on Norwegian theatre laws can be found in Norsk Lovtidende, 1st part, E. R. Baetzman, Christiania [Oslo] 1877, pp. 85-6.)

16 For more information on the different theatre prohibitions in Denmark-Norway, see Svein Gladsø, Teater mellom jus og politikk: studier $i$ norsk teater fra 1700-tallet til 1940, Unipub, Oslo 2004, pp. 8-16 and Bråten, op. cit. and Torkel Bråten, "Retten til å framføre offentlige fores- 
tillinger. Ytringsfrihet eller næringsfrihet?”, unpublished article, 2013, pp. 1-14.

17 Norway was ruled by Denmark until 1814, then shared the same monarchy with Sweden until 1905. Consequently, Norway did not develop a royal court theatre of its own. Christiania Theatre, which opened in 1828, became somewhat close to functioning as a national theatre, but dance was never prioritized there, even if several guest performers where featured.

18 The professional opera and ballet companies of Sweden and Denmark were developed during the seventeenth and eighteenth centuries and built on the European/ French model of an aristocratic ballet connected to royalty. See Marina Grut, Royal Swedish Ballet. A History from 1592 to 1962, Carina Ari Library publications, no. 6, Hildesheim, Olms 2007 and Aline Storm, The Royal Danish Ballet, The Royal Danish Theatre, Copenhagen 2005.

19 Fiskvik, "Nemo in orbe est", op. cit.

20 The older dancer was called Ritte Janson, and came from South Africa. This was reported in several Norwegian newspapers, for instance in the Egersundsposten, 9 May 1878.

21 The Goldkette Acrobat-pantomime og Balletselskab travelled in Norway in 1880 and 1881. For instance, the ensemble performed in Skien in September 1880. (Skiensposten, 15 September 1880.)

22 The repertoire of the Goldkette ensemble was stated as consisting of acrobatics, national dances and pantomimes in an advertisement in Sandefjord Blad, 4 May 1881.

23 Please note that the role of the wife/mother Catharina Altenburg is unclear because she is rarely mentioned in the source material. She is not listed as performer in advertisements, but likely filled other important functions.

24 Hans Marvig was possibly also Norwegian, whereas Catharina Altenburg was German. Together with their four children they toured Sweden and Norway in 1848 and 1849. See for instance advertisements in Den Norske Rigstidende, 13 May 1848.

25 For some of the children, their birth certificates are lost, for instance for Augusta Johannesén, who was born in Sundsvall. The church books of Sundsvall were destroyed in a fire in 1888 .

26 Marian Hannah Winter, The Pre-Romantic Ballet, Pitman, London 1974, p. 34.

27 Carl Sven Ludvig Marvig was born in Göteborg 16 Oc- tober 1837 . He worked as premier danseur at the opera in Stockholm 1859-62 and prior to this he danced at the royal opera of St. Petersburg. After his employment in Stockholm he performed at the Italian opera in Paris, before moving to the United States.

28 Hirn, Vàra danspedagoger och dansnöjen, op. cit., p. 88.

29 Christian Johansson (1817-1903) was originally Swedish, danced under Bournonville and continued his career at the Imperial ballet in St. Petersburg where he became a distinguished teacher with great influence.

30 See Idun, Praktisk Veckotidning for Qvinnan och Hemmet, Fritjof Hellberg, Stockholm, 18 January 1889.

31 The poster from Åbo 1860 is published as part of an electronic collection of the Åbo city: Offentliga nöjen $i$ Åbo under 1800-talet - en samling affischer, http://bibbild. abo.fi/nojen/1850-91/20.jpg.

32 Hirn, Våra danspedagoger och dansnöjen, op. cit., p. 88.

33 Rosenqvist, Artister i norr, op. cit., p.82.

34 Norrbotten Posten, 14 June 1877, 25 October 1878, cited in Rosenqvist, ibid., pp. 83, 156.

35 Susan $\mathrm{Au}$, "Character Dance" in The International Encyclopaedia of Dance, vol. 2, Selma Jean Cohen, ed., Oxford University Press, Oxford 1998, pp. 106-8.

36 Ibid, p. 108.

37 Garafola, op. cit., p. 3.

38 Yuri Slonimsky, The Bolshoi Ballet, Philosophical Library, New York 1960, p. 8.

39 According to Slonimsky, a new genre developed in Moscow at the turn of the nineteenth century inspired by the national comic opera-dance scenes suggested by folk festivals, games, Yule-tide and Shrovetide Festivals (ibid.).

40 The poster is for a performance on 26 November 1858 , http://hereditas.abo.fi/xmlui/bitstream/handle/123456789/1193/6.jpg? sequence $=1$.

41 Garafola, op. cit., p. 3.

42 Hirn assumed that the poster portrayed Augusta and Alfred based on their looks/estimated age. The poster is archived in the Russian National Library, newspaper section. The entire poster as well as information on it is published by Hirn, Den Gastronomiska Hästen, op. cit., pp.157, 219. It is probably the only preserved poster of the Johannesénske family's performances in St Petersburg.

43 The poster is unique because it is the only source found (so far) that give visual clues to what the dancing could have looked like. Interestingly, the illustration of the children is shown alongside the other 'highlights' offered 
in the St. Petersburg performance, such as a guest magician who was another major feature of the program.

44 Alexandra Carter, Dance and Dancers in the Victorian and Edwardian Music Hall Ballet, Ashgate, Aldershot 2005, p. 12.

45 Ibid.

46 For instance, the earlier mentioned itinerant dancer and acrobat Michael Stuart and his wife Christina Doreothea Stuart performed pantomimes during their Norwegian tour in 1769. (Fiskvik, Nemo in orbe est, op. cit.)

47 Sandefjord Blad, 4 May 1881.

48 Building on the nineteenth century repertoire, a variety of pantomimes are still performed as an independent art form at the Copenhagen Tivoli.

49 Advertisements in Tonsberg Blad, 30 May 1879.

50 Hirn refers to performances in Åbo (Finland) in May 1860. See Hirn, Vaira danspedagoger och dansnöjen, op. cit., pp. 88, 113.

51 Norrbotten Posten, 14 June 1877. Cited in Rosenqvist, Artister i norr, op. cit., p. 83.

52 Lena Hammergren, cited in Rethinking Dance History. A Reader, Alexandra Carter, ed., Routledge, London 2004, pp. 21-2.

53 Arkin and Smith, op. cit., p. 12.

54 Hirn, Vara danspedagoger och dansnöjen, op. cit., pp. 86-8.

55 For information on Gullberg, see Elvin Ottoson, Minns $d u$ det än...: ett avsnitt ur operettens historia, Fritzes bokförlag, Stockholm 1941, p. 149. 
